\title{
Aesthetic Response of Audiences' Behavior of Dangdut Koplo Music Performance
}

\section{Theresia Ratna Wiharyanti ${ }^{\bowtie}$, Totok Sumaryanto Florentinus, Udi Utomo}

\author{
Universitas Negeri Semarang, Indonesia
}

Submitted: August 13, 2020. Revised: September 9, 2020. Accepted: November 4, 2020

\begin{abstract}
Dangdut Koplo music performances are favored and watched by the public. This is able to generate an aesthetic response of the audiences, which is shown by their behavior. This study aims to examine the aesthetic response of audience behavior of dangdut koplo music performances in Pekalongan. This research uses qualitative methods, data collection using observation, interview, and document study techniques. Data analysis procedures used data reduction, data presentation, and data verification. The validity of the data used is triangulation, data sources, and theory. The results showed that the aesthetic response in the audience behavior of dangdut koplo music performance in Kalirejo village, Talun, Pekalongan Regency had a positive response that led to behavior, such as (1) dancing with friends in groups or alone; (2) Menyawer (giving some money); and (3) notice the show schedule. Based on the research results, it can be suggested: (1) can broaden the insight and description of the development of music, especially dangdut koplo music in the present era, (2) can be taken into consideration how the impact of dangdut koplo on the behavior of dangdut koplo music performances.
\end{abstract}

Keywords: aesthetic response; behavior; dangdut koplo; music

How to Cite: Wiharyanti, T. R., Florentinus, T. S., \& Utomo, U. (2020). Aesthetic Response of Audiences' Behavior of Dangdut Koplo Music Performance. Harmonia: Journal of Arts Research And Education, 20(2), 205-212

\section{INTRODUCTION}

Dangdut music is a type of popular music and is the most phenomenal music genre in Indonesia. Dangdut comes from the acculturation of other nations' music which came to Indonesia by combining several elements of musical genres, and they are Malay music, Gambus music, and Indian music (Wisnu, 2019). The combination of elements of Malay, Indian, and Gambus music makes dangdut have a strong appeal in the community.

Dangdut music is very easily accepted by all levels of society and grows rapidly to all corners of the country because this music has a distinctive musical style and has a lyrical theme that is easy to memorize because it usually takes the theme of everyday events that occur in many communities (Benny, 2017). Dangdut music has a very distinctive characteristic, i.e., the singing technique using the lilting cengkok followed by the beat of the gendhang, and is dominated by dance or jogetan.

Dangdut koplo as a form of dangdut music development began in the early to mid-1990s, and the peak era was in the post-Soeharto era. Dangdut koplo is developed in East Java. This was caused by the entry of jaipongan gendangan to East Java around the 1980s and developed in music

\footnotetext{
Corresponding author:

E-mail: theresiaratna030186@gmail.com
} 
playing in East Java (Weintraub, 2013).

The origin of the word dangdut is the same as dangdut koplo now. Traced back in 2008, the word Koplo means 'dungu' (in Javanese) or other meaning, i.e., koplo pills containingsychotropic substances (Raditya, 2013). The term koplo refers to the style of performance, drum rhythm, fast tempo. According to his definition, the term comes from "pil koplo", koplo music was a way of expressing drunken feelings about a dance style that people consider "hard to believe" or "magical" (Weintraub, 2013). That is what makes dangdut music easy to spread widely.

Dangdut koplo is a creation of dangdut music. When viewed from the organology used, there is no significant difference from dangdut music, like the musical instruments that are played, like guitar, keyboard, bass, drums, flute, and drums. The thing that distinguishes is how to play this instrument according to the interpretation of local players. The players interpret in their own style, and the most important thing in dangdut koplo is the kendhang game which produces a "dutt" sound. The kendhang sound is usually combined with the voices of players shouting like "uuuuu aaaa", "buka sitik joss" or screams which make the atmosphere even more lively and festive (Raditya, 2013).

Dangdut koplo has an element that is often used and makes it interesting, namely sengga'an. "Sengga'an" performed by a kendhang player accompanied by a shout while the singer is singing in front of the audience. This was done so that the atmosphere of the dangdut koplo music performance was even more festive.

Dangdut is a musical performance in Indonesia which is currently more popular in the community. This can be seen from the audience's crowd at the time of dangdut music performance (Muttaqin, 2006). The public is very enthusiastic about watching the dangdut koplo music show when a dangdut music show is held. The audience at the dangdut music show is not only adults, but children and teenagers also watch this show (Raditya, 2017).
In Pekalongan Regency, especially in Kalirejo village, Talun, dangdut koplo music is very popular with the surrounding community. With the proliferation of dangdut shows on local and private television stations, the prestige of dangdut music began to decline and has now returned to the top music charts in Indonesia.

The work of dangdut music, which is increasingly modern, has made dangdut music able to compete with other music genres. Dangdut koplo song themes raise the realities of everyday life in a language that is easily understood by the public. The language is straightforward, without being covered up so that it is easily accepted by any society (Risna, 2016).

Dangdut is more than the usual music genre. Dangdut can be more adaptive according to the times. This is a dangdut specialty because dangdut can accept musical elements from anywhere to be combined. In line with this, Lockard (1998) states that:

"Dangdut emerged from the cultural melting pot of Jakarta, a city sometimes compared to the spicy Indonesian salad gado-gado because of its assimilation and intermingling of peoples and ideas arriving from outside."

Response is a form of reaction that is expressed as an attitude, where the attitude arises based on the evaluation process in the individual, which concludes the stimulus in the form of good, bad, pleasant, unpleasant values then crystallizes as a potential reaction to the object. Azwar (2000). Response is also defined as a behavior or attitude that is tangible before detailed understanding, research, influence or rejection, likes or dislikes, and the use of certain phenomena. (Wulandari, 2018).

Dangdut koplo music performance can elicit an aesthetic response from the audience expressed in the form of behavior and actions with the object being observed. This can happen because the behavior that appears is an expression of the audience is enjoying a spectacle they observe.

People in Kalirejo village, Talun, Pekalongan Regency have an interest in 
dangdut koplo music. This is evidenced by every time there is a special celebration such as hajatan or anniversary, the people here always invite dangdut music groups. In fact, the current dangdut koplo music performance is not something weird and rare anymore. However, it can be said that this performance is a tradition for the community. Not only is it the identity of the Pantura (north coastal) people.

In Pekalongan Regency, Talun area, there is a dangdut koplo music group that is active as entertainment and is very well known by Pekalongan people. This music group is called Bonex, which comes from the village of Talun, Pekalongan Regency.

The dangdut koplo music group's presence has its own appeal for children and adults in appreciating this music. The form of appreciation appears in paying attention to what he admires. Every time a dangdut koplo music show is held, the public looks fascinated and can even express their feelings through the spoken words. However, there is also the opposite.

The audience's response to what they observe and see can be seen through the way they move, such as rocking. This response follows what other spectators or singers do while on stage. Mimicking movements and swaying is the audience's response to finding the freedom of expression.

A person's tendency to behave towards an object is a form of aesthetic response to dangdut koplo music performance (Azwar, 2000). This becomes very interesting when looking at the facts at the field that the audience/community who often watch dangdut koplo music performances have an aesthetic response that results in behavior towards this music.

Measuring the response is not an easy thing because the response is a person's tendency, view or stance to examine an object or problem, and act accordingly by realizing positive and negative feelings in dealing with an object. Stating the structure of the attitude or response to the counselor consists of components, including the affective component, the cognitive compo- nent, and the connotative component. (Azwar, 2000).

The research conducted by Benny (2017) discusses aspects of dangdut music that can affect drainage construction workers' morale. The loud dynamic or soft sound produced by the loudspeaker when the work accompaniment song is played will add to the drainage workers' enthusiasm and persistence. This research is in line with what researchers did in observing dangdut koplo music genre, which has the same goals, it is how much they like dangdut koplo music and how much dangdut music influences their daily lives. However, the target of the two researchers were different; they are children and adults. Children and adults have different rules in what they should know and what they shouldn't know.

This study will discuss the aesthetic response in audience behavior that appears at dangdut koplo music performance. The benefits of this research are expected to enrich and increase knowledge about concepts and theories, as well as insight into audience behavior in dangdut koplo music performances.

\section{METHODS}

This study used a qualitative research method with a phenomenological research design, the target of the research is to see the overall aesthetic response to the behavior of dangdut koplo performances. Data collection techniques were carried out by means of observation, interviews, and document study.

The observations made in this study were direct observations, i.e., a careful review of the phenomena in the dangdut koplo music performance in Kalirejo village, Talun, Pekalongan Regency. Interviews were conducted with dangdut koplo musicians, local communities, and the local audiences. Document studies were conducted to obtain data in the form of photos, audio and visual recordings related to dangdut koplo music performances. 
The data validity technique uses source triangulation, i.e. the process of testing validity can be done by examining the data that has been obtained through various sources. This technique is used to test the credibility of the data. Researchers conducted source triangulation through informants related to information about dangdut koplo music performance of Bonex Group.

The concepts of ethics and emic are also used in this study. The process for analyzing data was carried out by reducing the data followed by the presentation and verification of data related to the Bonex music group, as stated by Miles and Hubermen (Rohidi, 2011).

\section{RESULTS AND DISCUSSION}

\section{Dangdut Koplo Performance}

Dangdut koplo music performance is a music show featuring dangdut songs, and in its appearance, there are sounds of musical instruments such as guitars, drums, basses, drums, and keyboards. Dangdut koplo music performances are in great demand by all people, especially in Kalirejo Village, Talun, Pekalongan Regency.

The dangdut music group that was formed in Pekalongan Regency continues to grow. Almost every time there is a certain celebration, the people of the Talun area always invite dangdut koplo music group. One of the popular dangdut koplo music groups in Talun, Pekalongan is "BONEX".

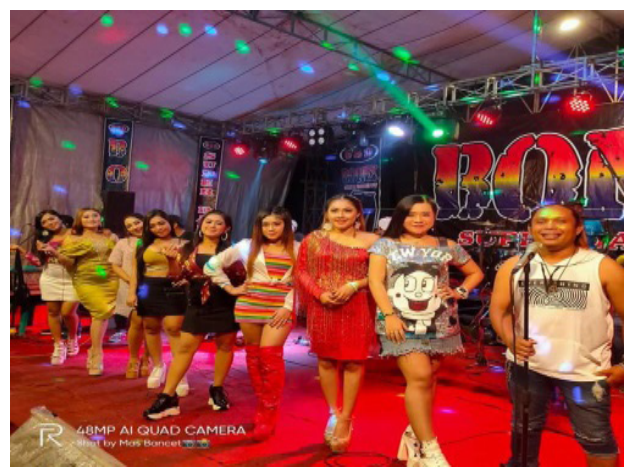

Figure 1. Personnel of dangdut koplo group Bonex

The dangdut koplo music group "Bo- nex" is dangdut koplo music group that often performs and provides entertainment throughout the city and Pekalongan Regency. The dangdut koplo music group "Bonex" is a dangdut genre music group that emphasizes the quality of music. The dangdut music performances presented can be enjoyed by all people, especially the people of Pekalongan Regency.

The main purpose of the formation of the dangdut koplo music group "Bonex" is to preserve the developing dangdut music and dangdut songs that are starting to disappear by the renewal of their musical arrangements. This allows people to recall dangdut songs that have begun to disappear and increasingly like dangdut music.

The concept of the dangdut koplo music group "Bonex", which consists of 6-7 personnel and is supported by attractive lighting and stage settings so as to attract people to use the services of this music group. This can be proven by the Bonex dangdut music group's frequent appearance to provide entertainment such as a wedding celebration, circumcision, or a celebration by their respective communities or villages. This is in line with the opinion of A'yun \& Rachman (2019); Rachman \& Utomo, 2018, 2019; Ramadhani \& Rachman, (2019) that a music will get more public attention if the presentation is attractive in terms of stage layout which includes lighting, decoration, performance venue, musical arrangement, as well as the novelty of the musical theme in accordance with the times.

Dangdut koplo music group "Bonex" also documents every show they present in the form of videos which are then published on their official social media accounts. This aims to promote the dangdut koplo music group "Bonex" to be known throughout Indonesian society, not only in Pekalongan.

Dangdut Koplo music performances are held at 19.00 WIB. The audience received information about the show from the surrounding environment as well as pamphlets/brochures spread on social media. The audience who came were not 
only from the local community but from various regions, especially loyal fans of the Bonex music group.

The show began with signs of musical accompaniment sounded to provoke the audience's attention that the show was about to begin. The audience is very excited to watch it. Although the weather at the time of the show was not good, heavy rain, hot, it did not stop the audience from keeping watching dangdut koplo music show until the show was over. Local people near the show's location arrive early to find a comfortable place to see the dangdut koplo music show.

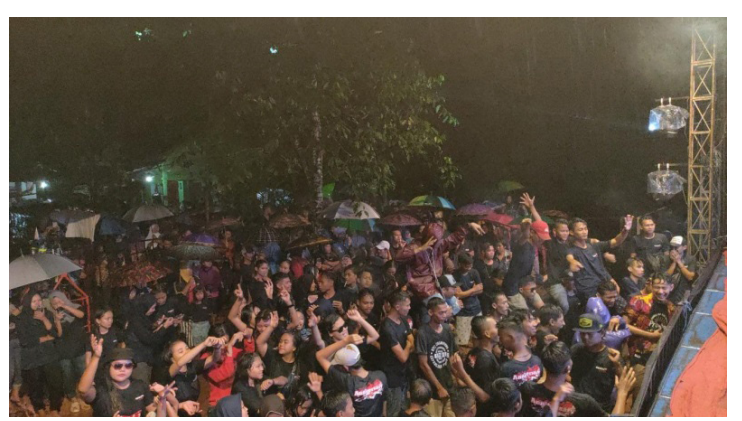

Figure 2. Audiences' appreciation

(Documentation: Ratna, 2020)

The audience really enjoyed dangdut koplo music show. They seem willing to be in the rain to watch dangdut koplo music show. The audience documented dangdut koplo music performance using their cellphones. They sing together with the group in the performance.

\section{Aesthetic Response Forms in Performing Behavior}

The response of the audiences towards dangdut koplo show can be seen from their enthusiastic in watching the show. It is in line with the opinion of (Azwar, 2000) that the response is a form of reaction which is expressed as an attitude where the attitude arises based on the evaluation process within the individual which concludes the stimulus in the form of good, bad, pleasant, unpleasant values then crystallizes as a potential reaction to the object

Dangdut music is music favored by everyone with a unique and interesting genre (Muttaqin, 2006). Dangdut koplo music performance was attended by the local community, including children and adults, but some audiences deliberately came from far / outside the region. This statement is in accordance with the phenomenon of dangdut music performances which are always watched by many people, from small children to adults, even the elderly, by generating different responses. The aesthetic response that appears in the dangdut koplo music show is in the form of movement by the audience through the process of observing and enjoying a song and music.

The aesthetic response of the audience after appreciating dangdut koplo music performance was expressed by rocking and dancing, but some were just silent while enjoying the show. This is in line with the opinion (Alex, 2003) that a response is also defined as a tangible behavior or attitude before detailed understanding, research, influence or rejection, like or dislike, and utilization of a certain phenomenon.

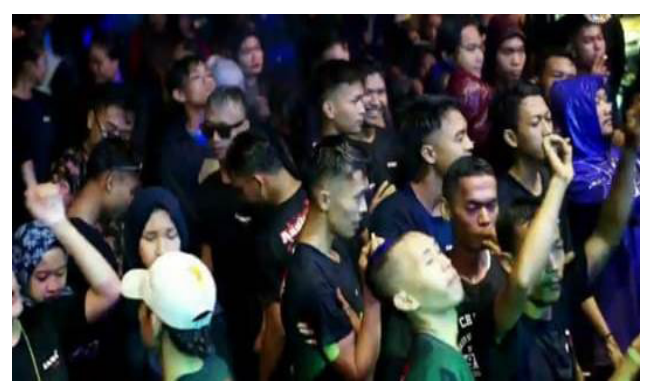

Figure 3. Forms of the audience's aesthetic response

(Documentation: Ratna, 2020)

The result of the audience's response to dangdut koplo music show was poured out dancing and rocking with their friends, it can be seen in the Figure that there are dancing alone or with their groups. This is in accordance with the statement (Kocho, 2013) that three factors influence a person's response: they are the person concerned who sees and tries to provide an interpretation of what he sees, he is influenced by attitudes, motives, interests and expectations. 
In dangdut koplo music show, dancing and swaying movements both with the groups and by themselves is a form and form of the audience's interpretation of what they have observed, seen and heard. A dangdut music show is in great demand by various groups and various regions. The behavior of singing, dancing together is always seen in dangdut music performances.

The research findings above occurred in dangdut koplo music performance in the Pekalongan area. Because of the massive response to dangdut music shows, the audience brings up behavior during the show.

\section{Dangdut Koplo Music Performance Be- havior}

The behavior that appears at the dangdut koplo music show in Kalirejo Village, Talun, Pekalongan Regency is that the audience is happy and enthusiastic. This is shown by a very positive response, causing various behaviors in the show that is being watched (Azwar, 2000).

During the performance, the behavior that they dance together with their friends, some are dancing alone, enjoying the pleasant music, and very fun to dance. However, some audiences just kept silent in enjoying the performance.

\section{Dancing or Swaying Behavior}

Dancing or rocking is a movement of moving the body from toe to head. In dangdut koplo music show, almost everyone who enjoys/watches the show has a positive response by shaking and dancing while following the music.

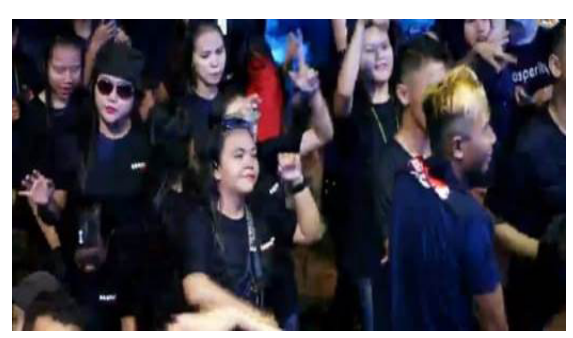

Figure 4. Self-dancing behavior (Documentation: Ratna, 2020)
Another thing is also seen in audiences who do not dance while watching dangdut music performances. They respond to dangdut music performances by just nodding their heads while following the beat.

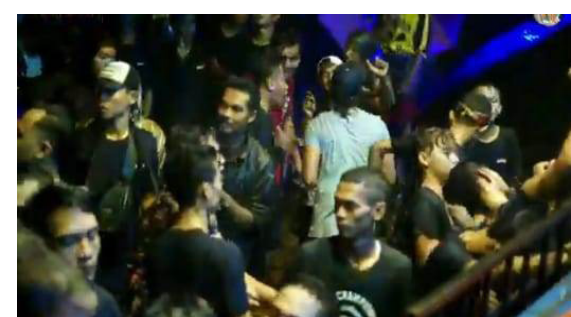

Figure 5. Dancing behavior in groups / groups (Documentation: Ratna, 2020)

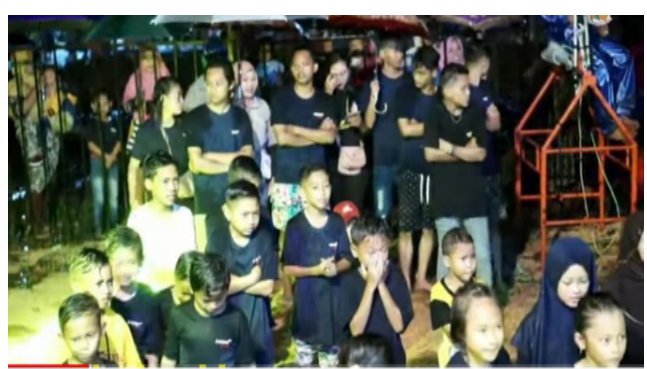

Figure 6. Behavior without dancing (Documentation: Ratna, 2020)

\section{Menyawer (giving some money) Behavior} Menyawer is a phenomenon that we usually see and observe in every Dangdut Koplo music show. Menyawer is giving money to a singer or musician that the audience likes or enjoys doing (Setyawan, 2018).

The form of response to dangdut koplo music performance in Kalirejo village, Talun, Pekalongan district, is showed by menyawer behavior (Risna, 2016) Menyawer activity is a phenomenon that we always see when there is a musical performance, especially dangdut koplo music.

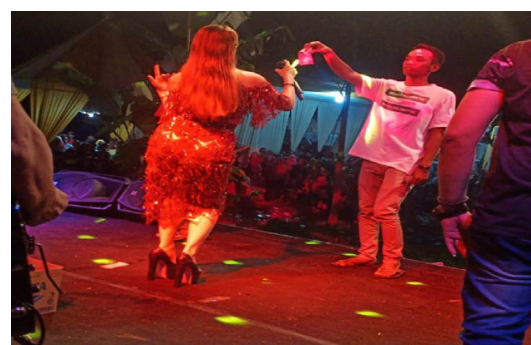

Figure 7. Menyawer activity (Documentation: Ratna, 2020) 
Behavior that arises from feeling happy and the intensity of being happy with an object or something by means of menyawer. The reason is that they are very satisfied with the song performed by the Bonex music group. So in return for satisfying services from the audience, they give money to the singer in the show.

\section{Behavior Following the Show Schedule}

The results of an interview with Mas Bancet, a fan of dangdut koplo music, arises from a sense of liking to dangdut music by always following and watching the Bonex group at every show held. They also formed a community called "sonata." Sonata is a community of dangdut koplo lovers which come from Pemalang, and they are very active in following the performance schedule of Bonex group.

The form of behavior that appears in a dangdut koplo music show occurs because of the audience's response to this music show. It also happens to people in Pekalongan area. They are very enthusiastic about dangdut koplo music performance in their area. This can be seen from the large number of audiences who watched the live music which was held at night. Even with the rainy weather, they remained enthusiastic and watched the show.

\section{CONCLUSION}

Based on the results and discussion, it can be concluded that the response can affect the behavior of people, both young and old or children. Dangdut koplo music performance attracted the public's attention, which led to the audience's response to this music show. The audience was very enthusiastic about watching the show; this led to an aesthetic response from it. This can be seen from the large audience who attended the show and the expressions that the audience gave in appreciating the dangdut koplo music show. The expressions that appear can be seen in the audience's movements and behavior while enjoying the songs.

The behavior that appears in dang- dut koplo music performance in Kalirejo Village are the behavior of dancing, alone or in the group, the behavior of just being quiet enjoying dangdut music, the behavior of menyawer their favorite singers, and the behavior of following whenever and wherever the bonex music group performed.

The positive response that emerges from the community is expected to be able to contribute to dangdut music as a function of cultural sustainability, community integration, and aesthetic assessment that is useful for society so that it continues to exist and be sustainable along with the times.

\section{REFERENCES}

Aesijah, S. (2010). Musik Dangdut: Suatu Kajian Bentuk Musik. Harmonia: Journal of Arts Research and Education, 10(1), 56058.

Ali, R. (2013). Musik dangdut di Group Bhaladika Semarang dalam Konteks Perubahan Budaya. Chatarsis, 2(1), 8-13.

Andaryani, E. T. (2011). Persepsi Masyarakat terhadap Pertunjukan Musik Dangdut Organ Tunggal. Harmonia: Journal of Arts Research and Education, 11(2), 164-172.

Azwar, S. (2000). Sikap Manusia. Yogyakarta: Pustaka Belajar.

A'yun, W. Q., \& Rachman, A. (2019). Keroncong in Jamaican Sound, Sebuah Inovasi dalam Melestarikan Musik Keroncong di Bandung. Jurnal Seni Musik, 8(1), 34-42.

Benny, F. (2017). Pengaruh Penggunaan Musik Dangdut Terhadap Semangat Kerja Para Pekerja Bangunan Drainase di Desa Margorejo Kabupaten Pati. Jurnal Seni Musik 6(2), 95-105.

Jazuli, M. (2001). Paradigma Seni Pertunjukan.Metode Penelitian Kualitatif. Semarang: Yayasan Lentera Budaya. Lockard, C. A. (1998). Dance of Life: Popular music and politics in Southeast Asia: Craig A. Lockard. Musicology Australia, 21(1), 68-69. 
Moleong, L. J. (2001). Metodologi Penelitian Kualitatif. Bandung: PT. Remaja Rosda Karya.

Moleong, L. J. (2005). Teknik Pengumpulan Data Dalam Penelitian Kualitatif. Pawiyatan, 1(1), 1-7.

Mulyawan, E. Y. (2018). Manajemen Seni Pertunjukan Pada Grup Orkes Senggol Tromol. Jurnal Seni Musik 3(1), 82-91.

Muttaqin, M. (2006). Musik Dangdut dan Keberadaanya di Masyarakat: Tinjauan dari segi Sejarah dan Perkembangannya. Harmonia: Journal of Arts Research and Education, 7(2).

Rachman, A., \& Utomo, U. (2018). Sing Penting Keroncong: Sebuah Inovasi Pertunjukkan Musik Keroncong di Semarang. Jurnal Pendidikan dan Kajian Seni, 3(1).

Rachman, A., \& Utomo, U. (2019). The Rhythm Pattern Adaptation of Langgam Jawa in Kroncong. Advances in Social Science, Education and Humanities Research, Volume 276 2nd International Conference on Arts and Culture (ICONARC 2018), 276(Iconarc 2018), 99-101.

Raditya, M. H. (2013). Dangdut Koplo: Selera Lokal Menjadi Selera Nasional. Jurnal Seni Musik, 2(2).

Raditya, M. H. (2017). Dangdut Koplo: Memahami Perkembangan Hingga Pelarangan. Jurnal Studi Budaya Nusantara, 1(1), 10-23.

Ramadhani, F. A., \& Rachman, A. (2019). Resistensi Musik Keroncong di Era Disrupsi: Studi Kasus pada O.K Gita Puspita di Kabupaten Tegal. Musikolastika: Jurnal Pertunjukan Dan Pendidikan Musik, 1(1), 41-51.

Risna, G. N. (2016). Eksistensi Grup Musik Dangdut Bharata Desa Bentar Kecamatan Salem Kabupaten Brebes. Harmonia: Journal of Arts Research and Education, 2-8.

Rohidi, T. R. (2011). Metodelogi Penelitian
Seni. Semarang: Cipta Prima Nusantara.

Septia, E. (2012). Bentuk Pertunjukan Orkes Dangdut Parodi Senggol Tromol Di Semarang: Kajian Bentuk Dan Fungsi. Harmonia: Journal of Arts Research and Education, 12(1), 32-41.

Setiaji, D. (2017). Tinjauan Karakteristik Dangdut Koplo Sebagai Perkembangan Genre Musik Dangdut. Jurnal Hande, 1(1),19-34.

Setyawan, B. W., \& Saddhono, K. (2018). Ceprotan Performing Art: A Traditional Folkart Based on Urband Legend. Harmonia: Journal of Arts Research and Education, 18(1), 67-73.

Wadiyo, W. (2004). Musik Dangdut Di Kalangan Remaja Kota Semarang (Dangdut Music of Adolescent Society in Semaramg City). Harmonia Journal of Arts Research and Education, 5(3), 65501.

Wadiyo, W. (2015). Music As An Integrated Education Tool for Preschool Students. Harmonia: Journal of Arts Research and Education, 15(2), 144-150.

Wadiyo, W. (2006). Seni sebagai Sarana Interaksi Sosial (Art as a Tool of Social Interactions). Harmonia Journal of Arts Research and Education, 7(2), 66168.

Weintraub, A. (2013). The Sound and Spectacle of Dangdut Koplo: Genre and Counter-Genre in East Java, Indonesia Asian Music Summer/fall. Intenational Art Journal, 44(2), 160-194.

Wisnu. (2019). Perkembangan Musik Dangdut Koplo Jawa Timur tahun 2003 sampai 2017. Avatara e- Journal Pendidikan Sejarah, 7(3).

Wulandari, D. (2018). Respon Estetis Anak Terhadap Kesenian Barongan Sidhung Riwut Di Kabupaten Blora. Jurnal Seni Tari, 7(2), 52-65.

Yusuf, L. S. (2010). Psikologi Perkembangan Anak dan Remaja. Bandung: PT. Remaja Rosdarkaya Offset. 